\title{
PENGARUH PELATIHAN, PENGALAMAN KERJA DAN KOMPETENSI SOSIAL TERHADAP KINERJA KARYAWAN PADA PT. COCA-COLA BOTTLING INDONESIA TBK (Studi Kasus Karyawan Bagian Penjualan)
}

\author{
Via Anggraini \\ Susanto \\ Fakultas Ekonomi Universitas Semarang (USM)
}

Diterima: April 2018. Disetujui: Juli 2018. Dipublikasikan: Oktober 2018

\begin{abstract}
Problems on the PT. Coca-Cola Bottling Indonesia, namely a decrease in the level of performance, with most respondents who are employees of the sales force PT. Coca-Cola Bottling Indonesia never reach its targets. Based on previous studies, the performance of the employees were allegedly influenced by training, job experience, and social competence. So it can be the formulation of the problem, namely how to improve the performance of employees to sales targets can be achieved. This study uses the training, job experience, and social competence as an independent variable and the performance of the employee as the dependent variable. The purpose of this study was to analyze the effect of training, job experience, and social competence to employee performance sales force PT. Coca-Cola Bottling Indonesia. This research population is employees of the sales force PT. Coca-Cola Bottling Indonesia totaling 432 employees and sampling using accidental sampling which produces samples totaling 81 employees. Data analysis techniques are used to solve the problem of this research is to use multiple regression analysis techniques. The results showed that there is a significant effect of training variable (X1), job experience variable (X2), and social competence variable $(X 3)$ on the performance of the employee $(Y)$.
\end{abstract}

Keywords : Training, Job Experience, Social Competence, and Employee Performance.

\begin{abstract}
ABSTRAK
Permasalahan pada PT. Coca-Cola Bottling Indonesia, yaitu penurunan tingkat kinerja, dimana sebagian besar responden yang merupakan karyawan bagian penjualan PT. Coca-Cola Bottling Indonesia tidak pernah mencapai target kinerjanya. Berdasarkan penelitian terdahulu, kinerja karyawan tersebut diduga dipengaruhi oleh pelatihan, pengalaman kerja, dan kompetensi sosial. Sehingga dapat ditarik perumusan masalah yaitu bagaimana meningkatkan kinerja karyawan agar target penjualan dapat tercapai. Penelitian ini menggunakan pelatihan, pengalamn kerja, dan kompetensi sosial sebagai variabel independen dan kinerja karyawan sebagai variabel dependen. Tujuan penelitian ini adalah untuk menganalisis pengaruh pelatihan, pengalamn kerja, dan kompetensi sosial terhadap kinerja karyawan bagian penjualan PT. Coca-Cola Bottling Indonesia. Populasi dalam penelitian ini adalah karyawan bagian penjualan PT. Coca-Cola Bottling Indonesia yang berjumlah 432 orang karyawan dan pengambilan sampel menggunakan teknik accidental sampling yang menghasilkan sampel berjumlah 81 orang karyawan. Teknik analisis data yang digunakan untuk memecahkan permasalahan dalam penelitian ini adalah menggunakan teknik analisis regresi linier berganda. Hasil menunjukkan bahwa terdapat pengaruh yang signifikan dari variabel pelatihan (X1), pengalaman kerja (X2), dan kompetensi sosial (X3) terhadap kinerja karyawan (Y).
\end{abstract}

Kata Kunci : $\quad$ Pelatihan, Pengalaman Kerja, Kompetensi Sosial, dan Kinerja Karyawan. 


\section{PENDAHULUAN}

Kemajuan suatu perusahaan tidak terlepas dari sumber daya manusia yang dimiliki. Sumber daya manusia memegang peranan penting dalam suatu perusahaan karena selalu berperan aktif dan dominan dalam setiap kegiatan perusahaan. Setiap perusahaan baik yang bergerak dalam sektor jasa maupun industri selalu berupaya untuk mengelola manajemen sumber daya manusia dengan cara-cara profesional untuk meningkatkan kinerja, maka hadirnya karyawan yang memiliki pelatihan, pengalaman kerja, dan kompetensi sosial sangat dibutuhkan.

PT. Coca-Cola Bottling Indonesia adalah perusahaan yang bergerak dalam bidang manufaktur yang memproduksi produk-produk minuman. Dalam upaya memenuhi kebutuhan masyarakat maka sumber daya sangat dibutuhkan. Target kerja yang dijadikan tolak ukur adalah unit krat penjualan minuman. Tenaga penjualan memiliki peranan penting untuk menjembatani hubungan antara perusahaan dengan pelanggan. Tenaga penjualan diharapkan mampu berkomunikasi dengan baik, mengenali dan menyampaikan nilai produk yang ditawarkan.

Dalam upaya meningkatkan kinerja, pelatihan sangat diperlukan bagi karyawan. Pelatihan merupakan serangkaian aktivitas yang dirancang untuk meningkatkan keahlian-keahlian, pengetahuan, pengalaman, ataupun perubahan sikap pegawai. Pelatihan digunakan untuk meningkatkan kinerja pegawai dan selanjutnya meningkatkan kinerja organisasi. Sinambela (2012) dalam Amani (2014) mengemukakan bahwa pelatihan membantu para pegawai untuk mengembangkan berbagai ketrampilan tertentu yang memungkinkannya untuk berhasil pada pekerjaan saat ini, dan mengambangkan pekerjaan di masa yang akan datang.

Peningkatan kinerja juga dapat dipengaruhi oleh pengalaman kerja yang telah dimiliki seseorang. Pengalaman kerja karyawan mencerminkan tingkat penguasaan pengetahuan dan ketrampilan yang dimiliki seorang karyawan dalam bekerja yang dapat diukur dari masa kerja dan jenis pekerjaan yang pernah dikerjakan karyawan. 
Pengalaman kerja adalah tingkat penguasaan pengetahuan dan ketrampilan yang dimiliki oleh karyawan dalam bekerja yang dapat diukur dengan masa kerja dan jenis pekerjaan yang pernah dikerjakan karyawan selama periode tertentu. Hal ini sejalan dengan teori yang dikemukakan oleh Robbins dan Timothy (2008) dalam Luh Aristarini, I Ketut Kirya, Ni Nyoman Yulianthini (2014), bahwa pengalaman kerja didasarkan pada pengetahuan dan ketrampilan yang dimiliki karyawan.

Kompetensi sosial yang dimiliki karyawan sangat penting dalam meningkatkan kinerja karyawan. Kompetensi sosial mencerminkan kemampuan karyawan untuk menjalin kerjasama serta berinteraksi dengan orang lain dalam bekerja untuk mencapai tujuan pribadi maupun tujuan organisasi. Kompetensi sosial yang rendah terlihat dari kurangnya kemampuan untuk berinteraksi dengan masyarakat. Kompetensi sosial adalah kemampuan untuk membangun dan memelihara hubungan kerja serta berinteraksi dengan orang lain dalam melaksanakan tugas sosial sebagai upaya untuk mencapai tujuan pribadi maupun tujuan organisasi. Hal ini sejalan dengan teori yang dinyatakan Spencer \& Spencer (1993) dalam Luh Aristarini, I Ketut Kirya, Ni Nyoman Yulianthini (2014), bahwa kompetensi sosial didasarkan pada kemampuan untuk membangun kerja sama dengan orang lain.

Secara teoritis apabila karyawan mendapatkan pelatihan ketrampilan menjual, pengalaman kerja dan kompetensi sosial maka akan dapat meningkatkan kinerja karyawan. Artinya semakin banyak pelatihan ketrampilan menjual, pengalaman kerja dan kompetensi sosial yang dimiliki maka kinerja karyawan akan semakin tinggi.

\section{TINJAUAN PUSTAKA}

\section{Kinerja}

Menurut Panggabean (2004:21), kinerja adalah kondisi dari sebuah kelompok dimana ada tujuan yang jelas dan tetap yang dirasakan menjadi penting dan terpadu dengan tujuan individu. Kinerja yang semakin baik akan dapat memacu perkembangan suatu perusahaan untuk menjadi lebih baik pula. 


\section{Pelatihan}

Menurut Handoko (2012:104) pelatihan (training) kegiatan yang dilakukan untuk memperbaiki penguasaan berbagai ketrampilan dan teknik pelaksanaan kerja tertentu, terinci dan rutin. Pelatihan menyiapkan para karyawan untuk melakukan pekerjaan-pekerjaan sekarang. Pelatihan mengacu kepada metode yang digunakan untuk memberikan karyawan baru atau yang ada saat ini dengan ketrampilan yang mereka butuhkan untuk melakukan pekerjaan.

\section{Pengalaman Kerja}

Pengalaman kerja karyawan mencerminkan tingkat penguasaan pengetahuan dan keterampilan yang dimiliki seorang karyawan dalam bekerja yang dapat diukur dari masa kerja dan jenis pekerjaan yang pernah dikerjakan karyawan. Hal tersebut sejalan dengan pendapat Maryoto (2007) dan Alwi (2001) dalam Luh Aristarini, I Ketut Kirya, Ni Nyoman Yulianthini (2014) yang menyatakan bahwa pengalaman kerja didasarkan pada masa kerja atau jangka waktu karyawan dalam bekerja. Banyaknya pengalaman kerja yang dimiliki seorang karyawan ditentukan oleh masa kerja atau lamanya seseorang itu bekerja.

\section{Kompetensi Sosial}

Kompetensi sosial adalah karakteristik sikap dan perilaku atau kemauan dan kemampuan untuk membangun simpul-simpul kerja sama dengan orang lain yang relatif bersifat stabil ketika menghadapi permasalahan di tempat kerja yang terbentuk yang terbentuk melalui sinergi antara watak, konsep diri, motivasi internal serta kapasitas pengetahuan sosial Imam Sugeng (2002) dalam Winanti (2012). Spencer \& Spencer (1993) dalam Luh Aristarini, I Ketut Kirya, Ni Nyoman Yulianthini (2014) mengemukakan bahwa kompetensi sosial didasarkan pada kemampuan untuk membangun kerja sama dengan orang lain. 


\section{Penelitian Terdahulu}

Penelitian Amani (2014) dengan judul Analisa Pengaruh Pelatihan Ketrampilan Menjual terhadap Kinerja Tenaga Penjualan (Studi Kasus PT. Tiga Serangkai Pustaka Mandiri Departemen Distribusi General Book Area Jawa Tengah).

Penelitian Hanung Yulistiono Putro dan Susanto (2014) dengan judul Analisis Pengaruh Pelatihan, Kompensasi Dan Kepemimpinan Terhadap Kinerja Karyawan (Studi Kasus Pada Karyawan Sales Force PT. Indosat Tbk Semarang).

Penelitian Luh Aristarini, I Ketut Kirya, Ni Nyoman Yulianthini (2014) dengan judul Pengaruh Pengalaman Kerja, Kompetensi Sosial dan Motivasi Kerja Terhadap Kinerja karyawan pada Bagian Pemasaran PT. Adira Finance Singaraja.

\section{Kerangka Pemikiran}

Untuk lebih memperjelas arah dari penelitian yang menunjukkan bahwa ada pengaruh antara pelatihan, pengalaman kerja, dan kompetensi sosial terhadap kinerja karyawan, maka dalam penelitian ini dapat diambil suatu jalur pemikiran yang diterjemahkan dalam diagram struktur seperti pada gambar berikut:

\section{Gambar 1}

\section{Kerangka Pemikiran}

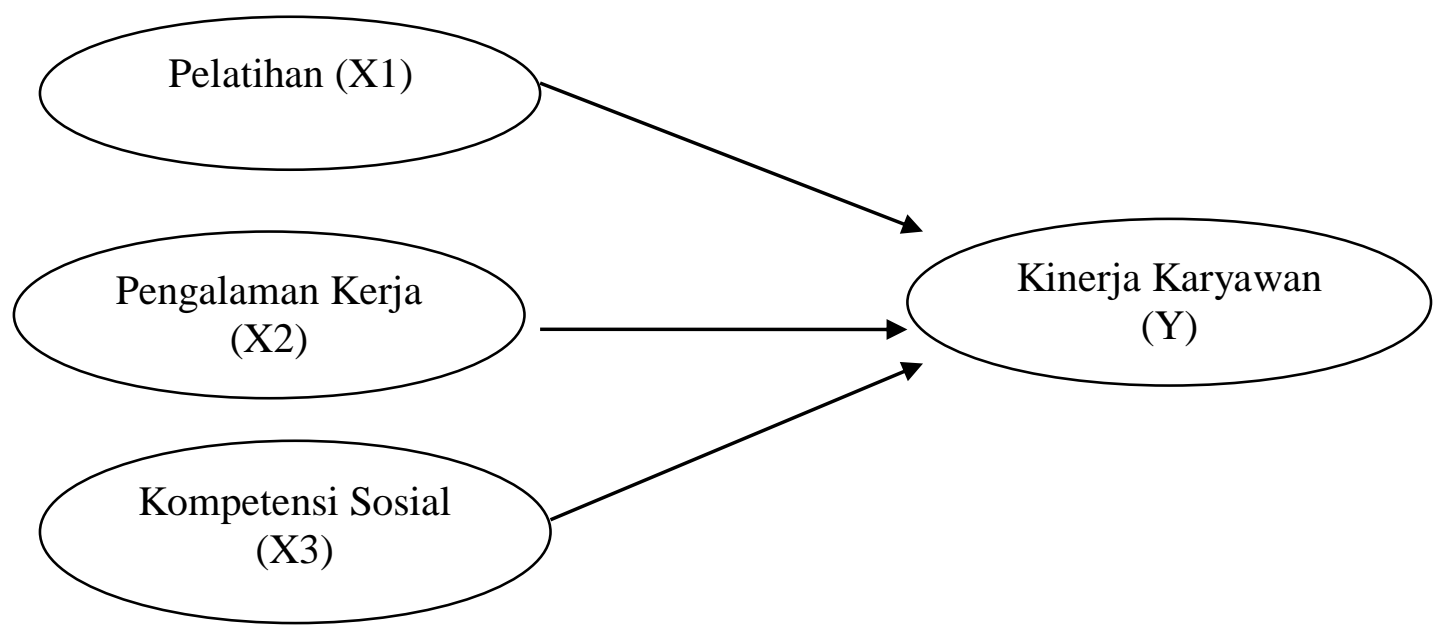




\section{Perumusan Hipotesis}

\section{Pengaruh Pelatihan terhadap Kinerja Karyawan}

Pelatihan merupakan serangkaian aktivitas yang dirancang untuk meningkatkan keahlian-keahlian, pengetahuan, pengalaman, ataupun perubahan sikap karyawan. Pelatihan digunakan untuk meningkatkan kinerja pegawai dan selanjutnya meningkatkan kinerja organisasi. Sinambela (2012) dalam jurnal Amani (2014) mengemukakan bahwa pelatihan membantu para pegawai untuk mengembangkan berbagai ketrampilan tertentu yang memungkinkannya untuk berhasil pada pekerjaan saat ini, dan mengembangkan pekerjaannya di masa yang akan datang.

H1 : Pelatihan berpengaruh terhadap kinerja karyawan.

\section{Pengaruh Pengalaman Kerja terhadap Kinerja Karyawan}

Robbins dan Timothy (2008) dalam jurnal Luh Aristarini, I Ketut Kirya, Ni Nyoman Yulianthini (2014) berpendapat bahwa pengalaman kerja didasarkan pada pengetahuan dan ketrampilan yang dimiliki oleh karyawan. Pendapat lain dikemukakan oleh Maryoto (2007) dan Alwi (2001) dalam jurnal Luh Aristarini, I Ketut Kirya, Ni Nyoman Yulianthini (2014) yang menyatakan bahwa pengalaman kerja didasarkan pada masa kerja atau jangka waktu karyawan dalam bekerja.

H2 : Pengalaman kerja berpengaruh terhadap kinerja karyawan.

\section{Pengaruh Kompetensi Sosial terhadap Kinerja Karyawan}

Spencer \& Spencer (1993) dalam jurnal Luh Aristarini, I Ketut Kirya, Ni Nyoman Yulianthini (2014) mengemukakan bahwa kompetensi sosial didasarkan pada kemampuan untuk membangun kerja sama dengan orang lain. Pendapat lain dikemukakan oleh Hariandja (2002) dan Hasibuan (2012) dalam jurnal Luh Aristarini, I Ketut Kirya, Ni Nyoman Yulianthini (2014) bahwa kompetensi sosial didasarkan pada kemampuan karyawan dalam memelihara hubungan kerja sama dengan orang lain.

H3 : Kompetensi sosial berpengaruh terhadap kinerja karyawan. 


\section{METODE PENELITIAN}

\section{Populasi dan Penentuan Sampel}

Populasi adalah gabungan dari seluruh elemen yang berbentuk peristiwa, hal atau orang yang memiliki karakteristik yang serupa yang menjadi pusat perhatian seorang peneliti karena itu dipandang sebagai sebuah semesta penelitian (Ferdinand, 2013:171). Populasi dalam penelitian ini adalah seluruh karyawan bagian penjualan PT. Coca-Cola Bottling Indonesia. Jumlah populasi dalam penelitian ini adalah sebanyak 432 orang karyawan bagian penjualan.

Sampel merupakan subset dari populasi, terdiri dari beberapa anggota populasi (Ferdinand, 2013: 171). Model pengambilan sampel yang digunakan dalam penelitian ini adalah accidental sampling yaitu pengambilan sampel yang dilakukan secara kebetulan atau ada kepada karyawan bagian penjualan di PT. Coca-Cola Bottling Indonesia. Sampel yang digunakan dalam penelitian ini berjumlah 81 karyawan bagian penjualan.

\section{Jenis dan Sumber Data}

Sumber data dalam penelitian ini diperoleh secara langsung yaitu melalui penyebaran kuesioner dan secara tidak langsung (melalui arsip atau dokumen perusahaan).

\section{Metode Pengumpulan Data}

Metode pengumpulan data yang digunakan dalam penelitian ini adalah dengan menggunakan kuesioner.

\section{Metode Analisis Data}

\section{Regresi Linier Berganda}

Analisis ini digunakan untuk mengetahui seberapa besar pengaruh variabel bebas pelatihan (X1), pengalaman kerja (X2), dan kompetensi sosial (X3) terhadap 
variabel terikatnya yaitu kinerja karyawan (Y). Persamaan regresi linier berganda adalah sebagai berikut (Ghozali, 2011):

$$
\mathrm{Y}=\mathrm{a}+\mathrm{b} 1 \mathrm{X} 1+\mathrm{b} 2 \mathrm{X} 2+\mathrm{b} 3 \mathrm{X} 3+\mathrm{e}
$$

Dimana:

$$
\begin{array}{ll}
\mathrm{Y} & =\text { Kinerja Karyawan } \\
\mathrm{a} & =\text { Konstanta }
\end{array}
$$

$\mathrm{X} 1, \mathrm{X} 2, \mathrm{X} 3$ = Pelatihan, Pengalaman kerja, Kompetensi sosial

$\mathrm{b} 1, \mathrm{~b} 2, \mathrm{~b} 3=$ Koefisien regresi

e $\quad=$ standar error

\section{Uji Signifikasi Pengaruh Parsial (Uji t)}

Uji statistik t digunakan untuk menguji signifikasi hubungan antara variabel $\mathrm{X}$ dan Y, apakah variabel bebas benar-benar berpengaruh terhadap variabel terikat secara terpisah atau parsial (Ghozali, 2012). Hipotesis yang digunakan dalam pengujian ini adalah:

Ho : Variabel-variabel bebas (pelatihan, pengalaman kerja, kompetensi sosial) tidak mempunyai pengaruh yang signifikan terhadap variabel terikat (kinerja karyawan).

Ha : Variabel-variabel bebas (pelatihan, pengalaman kerja, kompetensi sosial) mempunyai pengaruh yang signifikan terhadap variabel terikat (kinerja karyawan).

Dasar pengambilan keputusan (Ghozali, 2012:99) adalah dengan menggunakan angka probabilitas signifikasi, yaitu:

a) Apabila angka probabilitas signifikansi > 0,05, maka Ho diterima dan $\mathrm{Ha}$ ditolak.

b) Apabila angka probabilitas signifikansi < 0,05, maka Ho ditolak dan Ha diterima.

Membandingkan nilai t hitung dengan t tabel (Ghozali, 2012:99). 
a) Apabila t hitung $>\mathrm{t}$ tabel maka Ho ditolak dan Ha diterima.

b) Apabila t hitung $<\mathrm{t}$ tabel maka Ho diterima dan Ha ditolak.

\section{Koefisien Determinasi $\left(\mathbf{R}^{2}\right)$}

Koefisien determinasi $\left(\mathrm{R}^{2}\right)$ pada intinya mengukur seberapa jauh kemampuan model dalam menerangkan variasi variabel terikat. (Ghozali,97:2012). Nilai koefisien determinasi adalah antara nol dan satu. Nilai $\mathrm{R}^{2}$ yang kecil berarti kemampuan variabel-variabel bebas dalam menjelaskan variasi variabel-variabel terikat amat terbatas. Nilai yang mendekati satu berarti variabel-variabel bebas memberikan hampir semua informasi yang dibutuhkan untuk memprediksi variasi variabel terikat.

\section{HASIL DAN PEMBAHASAN}

\section{Hasil Analisis Regresi}

Pengolahan data dengan program SPSS versi 20 memberikan nilai koefisien persamaan regresi sebagai berikut pada tabel 1 sebagai berikut:

Tabel 1

Tabel Koefisien Regresi Linear Berganda

Coefficients $^{a}$

\begin{tabular}{|c|c|c|c|c|c|c|c|}
\hline \multirow[t]{2}{*}{ Model } & \multicolumn{2}{|c|}{$\begin{array}{l}\text { Unstandardized } \\
\text { Coefficients }\end{array}$} & \multirow{2}{*}{$\begin{array}{c}\text { Standardized } \\
\text { Coefficients } \\
\text { Beta }\end{array}$} & \multirow[t]{2}{*}{$\mathrm{t}$} & \multirow[t]{2}{*}{ Sig. } & \multicolumn{2}{|c|}{$\begin{array}{l}\text { Collinearity } \\
\text { Statistics }\end{array}$} \\
\hline & $B$ & Std. Error & & & & Tolerance & VIF \\
\hline (Constant) & 3.711 & .753 & & 4.929 & .000 & & \\
\hline Pelatihan & .243 & .051 & .423 & 4.752 & .000 & .554 & 1.806 \\
\hline PengalamanKerja & .113 & .053 & .188 & 2.126 & .037 & .564 & 1.775 \\
\hline KompetensiSosial & .190 & .040 & .368 & 4.760 & .000 & .733 & 1.365 \\
\hline
\end{tabular}

a. Dependent Variable: KinerjaKaryawan

Sumber : data primer yang diolah, 2016

$$
Y=0,423 X 1+0,188 X 2+0,368 X 3
$$


Dari persamaan regresi linier tersebut menunjukkan bahwa:

1. Nilai koefisien regresi variabel pelatihan (X1) bernilai positif sebesar 0,423 . Artinya, ada pengaruh positif antara pelatihan terhadap kinerja karyawan. Jika variabel pelatihan ditingkatkan maka kinerja karyawan akan meningkat pula.

2. Nilai koefisien regresi variabel pengalaman kerja bernilai positif sebesar 0,188. Artinya, ada pengaruh positif antara pengalaman kerja terhadap kinerja karyawan. Jika variabel pengalaman kerja semakin banyak maka kinerja karyawan akan meningkat pula.

3. Nilai koefisien regresi variabel kompetensi sosial bernilai positif sebesar 0,368. Artinya, ada pengaruh positif antara kompetensi sosial terhadap kinerja karyawan. Jika variabel kompetensi sosial ditingkatkan maka kinerja karyawan akan meningkat pula.

\section{Hasil Uji t}

Uji $\mathrm{t}$ digunakan untuk menguji hipotesis adanya pengaruh pelatihan, pengalaman kerja, dan kompetensi sosial terhadap kinerja karyawan secara parsial (sendiri-sendiri) pada tingkat signifikan $\alpha=0,05$.

1. Pengaruh pelatihan terhadap kinerja karyawan didapat $\mathrm{t}$ hitung $=4,752$ dengan sig $=0,000$. Karena nilai thitung $>$ ttabel dan nilai sig. $<\operatorname{sig} \alpha(0,05)$, maka HO ditolak dan Ha diterima. Artinya, hipotesis penelitian ini yang menyatakan "Pelatihan berpengaruh terhadap Kinerja Karyawan".

2. Pengaruh pengalaman kerja terhadap kinerja karyawan didapat $\mathrm{t}$ hitung $=$ 2,126 dengan sig $=0,037$. Karena nilai thitung $>$ ttabel dan nilai sig. $<\operatorname{sig} \alpha$ $(0,05)$, maka H0 ditolak dan Ha diterima. Artinya, hipotesis penelitian ini yang menyatakan "Pengalaman kerja berpengaruh terhadap Kinerja Karyawan".

3. Pengaruh kompetensi sosial terhadap kinerja karyawan didapat $t$ hitung $=$ 4,760 dengan sig $=0,000$. Karena nilai thitung $>$ ttabel dan nilai sig. $<\operatorname{sig} \alpha$ $(0,05)$, maka H0 ditolak dan Ha diterima. Artinya, hipotesis penelitian ini 
yang menyatakan "Kompetensi sosial berpengaruh terhadap Kinerja Karyawan".

\section{Analisis Koefisien Determinasi $\left(\mathbf{R}^{2}\right)$}

Maksud dan tujuan koefisien determinasi adalah mengukur besarnya kemampuan model persamaan regresi (independen variabels) dalam menerangkan variabel terikat.

\section{Tabel 2}

Tabel Koefisien Determinasi

Model Summary

\begin{tabular}{|l|r|r|r|r|}
\hline Model & \multicolumn{1}{|c|}{$\mathrm{R}$} & R Square & \multicolumn{1}{|c|}{$\begin{array}{c}\text { Adjusted R } \\
\text { Square }\end{array}$} & $\begin{array}{c}\text { Std. Error of the } \\
\text { Estimate }\end{array}$ \\
\hline 1 & $.814^{\mathrm{a}}$ & .662 & .649 & .5062 \\
\hline
\end{tabular}

a. Predictors: (Constant), KompetensiSosial, PengalamanKerja,

Pelatihan

b. Dependent Variable: KinerjaKaryawan

\section{Sumber:data primer yang diolah, 2016}

Pada tabel diatas didapatkan nilai Adjusted $\mathrm{R}^{2}$ diperoleh koefisien determinasi (adjusted $R$ Squarese) yaitu sebesar 0,649 yang artinya 64,9\% kinerja karyawan di PT. Coca-Cola Bottling Indonesia dipengaruhi oleh variabel pelatihan, pengalaman kerja, dan kompetensi sosial sedangkan sisanya dipengaruhi oleh variabel lain yang tidak diteliti dalam penelitian ini.

\section{Pembahasan}

Berdasarkan uji hipotesis 1 didapatkan hasil thitung $=4,752>$ ttabel $=1,989$ dengan sig $0,000<0,05$, dan nilai koefisien regresi sebesar 0,423 , sehingga disimpulkan bahwa hipotesis 1 diterima, yang artinya bahwa variabel pelatihan berpengaruh terhadap kinerja karyawan. Semakin sering pelatihan diberikan kepada karyawan maka akan semakin baik pula kinerja yang dihasilkan, karena pelatihan tersebut dapat meningkatkan partisipasi karyawan dalam volume 
pekerjaan untuk mengejar target, membangkitkan minat, meningkatkan pengetahuan, dan memberi kesempatan pada karyawan untuk lebih maju. Misalnya dengan diadakan pelatihan tentang basic salesmanship sehingga dapat merangsang partisipasi karyawan untuk lebih produktif dalam mencapai target. Pelatihan juga dapat diadakan di luar lingkungan perusahaan agar karyawan lebih tertarik dalam mengikuti pelatihan. Pelatihan dilakukan tidak dalam jangka waktu yang sangat lama agar tingkat pengetahuan yang dimiliki terus bertambah sehingga dapat mendukung pekerjaan. Selain itu, memberikan pelatihan tentang kedisiplinan kerja yang akan dapat menumbuhkan rasa percaya diri sehingga karyawan lebih mampu bekerja mandiri dan semakin meningkatkan kualitas kerjanya.

Berdasarkan uji hipotesis 2 didapatkan hasil thitung $=2,126>$ ttabel $=1,989$ dengan sig $0,037<0,05$, dan nilai koefisien regresi sebesar 0,188 , sehingga disimpulkan bahwa hipotesis 2 diterima, yang berarti bahwa variabel pengalaman kerja berpengaruh terhadap kinerja karyawan. Semakin banyak pengalaman yang dimiliki karyawan maka akan semakin baik pula kinerja yang dihasilkan, kinerja karyawan akan meningkat karena karyawan telah memiliki masa waktu atau masa kerja yang lama, tingkat pengetahuan dan ketrampilan yang lebih, dan penguasaan terhadap pekerjaan. Misalnya pada saat proses perekrutan karyawan, pihak HDR memberikan kententuan tentang minimal masa kerja, pengetauan dan kemampuan khusus yang berkaitan dengan jenis pekerjaan yang akan diisi, serta telah berpengalaman di bidang penjualan agar lebih mudah menguasai pekerjaan.

Berdasarkan uji hipotesis 3 didapatkan hasil thitung $=4,760>$ ttabel $=1,989$ dengan sig $0,000<0,05$, dan nilai koefisien regresi sebesar 0,040, sehingga disimpulkan bahwa hipotesis 3 diterima, yang berarti bahwa variabel kompetensi sosial berpengaruh terhadap kinerja karyawan. Semakin baik kompetensi sosial yang dimiliki karyawan maka akan semakin baik pula kinerja yang dihasilkan, kinerja karyawan akan meningkat karena karyawan mampu meyakinkan dan mempengaruhi orang lain, memahami posisi dalam berorganisasi, membangun dan memelihara jaringan kerjasama, dan bekerja sama dengan orang lain untuk mencapai solusi yang bermanfaat bagi semua pihak. Misalnya adanya peraturan untuk karyawan selalu bersikap ramah agar mudah beradaptasi dengan lingkungan 
baru sehingga dengan mudah untuk mempengaruhi konsumen untuk membeli produknya. Perusahaan menumbuhkan tingkat kesadaran karyawan tentang posisinya dalam suatu organisasi sehingga karyawan akan lebih terpacu dalam menyelesaikan pekerjaan sesuai target. Pimpinan bagian mengajak karyawan untuk selalu memelihara kerja sama baik dengan rekan kerja atau pihak lain, selain itu pimpinan juga harus menekankan pentingnya menciptakan kerja sama yang baik antar rekan kerja atau pihak lain demi peningkatkan kinerja karyawan.

\section{PENUTUP}

\section{Kesimpulan}

Berdasarkan hasil penelitian maka dapat disimpulkan sebagai berikut:

1. Ada pengaruh signifikan pelatihan terhadap kinerja karyawan. Hal ini berarti apabila pelatihan mengalami peningkatan maka kinerja karyawan akan meningkat.

2. Ada pengaruh signifikan pengalaman kerja terhadap kinerja karyawan. Hal ini berarti apabila pengalaman kerja mengalamni peningkatan maka kinerja karyawan akan meningkat.

3. Ada pengaruh signifikan kompetensi sosial terhadap kinerja karyawan. Hal ini berarti apabila kompetensi sosial mengalamni peningkatan maka kinerja karyawan akan meningkat.

4. Berdasarkan hasil analisis regresi berganda dapat disimpulkan bahwa variabel yang memiliki pengaruh terbesar terhadap kinerja karyawan adalah variabel pelatihan yang memiliki nilai koefisien regresi (beta) lebih besar dibanding variabel lainnya yaitu sebesar 0,423 dan pengalaman kerja yang memiliki koefisien regresi terkecil yaitu sebesar 0,188 .

\section{Saran}

1. Perusahaan sebaiknya meningkatkan pelatihan tentang kedisiplinan kerja sehingga karyawan mampu untuk bekerja mandiri dan lebih berkembang. 
2. Perusahaan sebaiknya dalam menempatkan karyawan disesuaikan dengan kemampuan kerja karyawan, sehingga tingkat penguasaan dan keterampilan yang dimiliki karyawan dapat sesuai dengan tuntutan pekerjaan.

3. Perusahaan sebaiknya melakukan pendekatan kepada karyawan, sehingga karyawan mau untuk menyampaikan permasalahan yang ada dalam dirinya.

4. Pihak perusahaan dalam proses perekrutan memberi persyaratan yang detail tentang pengalaman kerja dan kompetensi sosial yang dimiliki. Misalnya telah memiliki pengalaman kerja di bagian yang sama, mampu bekerja sama dengan pihak lain secara baik, dan memiliki keahlian di bidang penjualan.

\section{DAFTAR PUSTAKA}

Amani. 2014. "Analisa Pengaruh Pelatihan Ketrampilan Menjual Terhadap Kinerja Penjualan (Studi Kasus PT Tiga Serangkai Pustaka Mandiri Departemen General Book Area Jawa Tengah)”.

Arsiani Luh, I Ketut Kirya, Ni Nyoman Yulianthini. 2014. “Pengaruh Pengalaman Kerja, Kompetensi Sosial dan Motivasi Kerja Terhadap Kinerja Karyawan Pada Bagian Pemasaran PT Adira Finance Singaraja”. Jurnal Bisama Universitas Pendidikan Ganesha Jurusan Manajemen, Volume 2.

Dessler, Gary. 2003. Manajemen Sumber Daya Manusia. Edisi Kesepuluh, Jakarta : PT Indeks.

Ferdinand, Augusty. 2013. Metodologi Penelitian Manajemen : Pedoman Penelitian Untuk Penulisan Skripsi Tesis dan Disertasi Ilmu Manajemen, Edisi 4. Badan Penerbit Universitas Diponegoro.

Foster, Bill. 2001. Pembinaan Untuk Peningkatan Kinerja Karyawan. Jakarta : PPM. 
http://skripsi-manajemen.blogspot.co.id/2011/02/pengertian-pengalamankerja.html

Ghozali, Imam. 2009. Aplikasi Analisis Multivariate dengan Program SPSS, BPFE Undip, Semarang.

. 2012. Aplikasi Analisis Multivariate dengan Program SPSS, BPFE Undip, Semarang.

Handoko, T Hani. 2008. Dasar Dasar Manajemen Produksi dan Operasi. Cetakan Kesepuluh, BPFE Yogyakarta.

. 2012. Manajemen Personalia dan Sumber Daya Manusia, Edisi Kedua, BPFE Yogyakarta.

Hasibuan, Malayu S.P. 2002. Manajemen Sumber Daya Manusia, Edisi Revisi. Jakarta : PT Bumi Aksara.

. 2008. Manajemen Sumber Daya Manusia, Edisi Revisi. Jakarta : PT Bumi Aksara.

Mangkuprawira, Sjafri. 2002. Manajemen Sumber Daya Manusia Strategik. Cetakan Pertama. Jakarta : Ghalia Indonesia.

Moeheriono. 2012. Pengukuran Kinerja Berbasis Kompetensi, Edisi Revisi. Jakarta : PT Raja Grafindo Persada.

Panggabean, Mutiara S. 2004. Manajemen Sumber Daya Manusia. Bogor : Ghalia Indonesia.

Putro, Hanung Yulistiono, Susanto. 2014. "Analisis Pengaruh Pelatihan, Kompensasi dan Kepemiimpinan Terhadap Kinerja Karyawan (Studi Kasus Pada Karyawan Sales Force PT Indosat TBK Semarang)”.

Robbins, Stephen. 2007. Perilaku Organisasasi. Jakarta : PT Indeks Kelompok Gramedia. 
Siagian, Sondang P. 2011. Manajemen Sumber Daya Manusia. Jakarta : Bumi Aksara.

Simamora, H. 2014. Manajemen Sumber Daya Manusia. Yogyakarta : STIE YKPN.

Sugiyono. 2007. Statistika Untuk Penelitian. Bandung : Alfabeta.

. 2010. Metode Penelitian Bisnis. Bandung : Alfabeta.

.2012. Metode Penelitian Bisnis. Bandung : Alfabeta.

Umar, Husein. 2003. Metode Riset Akuntansi Terapan, Cetakan Pertama. Jakarta : Ghalia Indonesia.

Winanti, Marliana Budhiningtias. 2012. "Pengaruh Kompetensi Terhadap Kinerja Karyawan (Survei Pada PT Frisian Flag Indonesia Wilayah Jawa Barat)". Majalah Ilmiah Unikom, Volume 7 No.2.

Wirawan. 2012. Evaluasi Kerja Sumber Daya Manusia : Teori, Aplikasi dan Penelitian. Jakarta : Salemba Empat. 